selected at random from the cranial stumps of the anterior and posterior rami of the eighth nerve of the frog, Ross ${ }^{3}$ described gravity responses from the anterior ramus which were presumed to be derived from the utriculus and generally reacted to one only of two opposite directions of tilting in the 'maximally stimulating' plane. The reaction obtained from the posterior ramus also included typical gravity responses, the accurate localization of which was, however, impossible.

Single-unit discharges from the vestibular nucleus of the brain-stem of the cat were recorded by Adrian ${ }^{12}$, who was able to distinguish between gravity-controlled and rotation-controlled responses. The gravity receptors were increasingly stimulated during displacement from the normal. In the level position a low-frequency resting discharge was sometimes found which could be abolished by tilting in one direction and increased by tilting in the opposite direction. Response to lateral tilt and to fore-and-aft tilting was found to be separately localized in the vestibular nucleus, but Adrian points out in the discussion of his results that this does not necessarily imply their localization in two different otolith organs.

A discussion of these findings in comparison with the evidence reported in the present communication will be appended to the forthcoming full account of the work.

${ }^{1}$ Lowenstein, O., Biol. Rev., 11, 113 (1936).

'Ashcroft, D. W., and Hallpike, C. S., J. Laryngol., 49, 450 (1934).

' Ross, D. A., J. Physiol., 84, 14P (1935); 86, 117 (1936).

Lowenstein, O., and Sand, A., J. Exp. Biol., 13, 416 (1936).

${ }^{5}$ Lowenstein, O., J. Exp. Biol., 14, 473 (1937).

'Lowenstein, O., and Sand, A., J. Physiol., 99, 89 (1940).

' Lorente de Nó, R., Ergebn. Physiol., 32, 73 (1931).

${ }^{8}$ Lowenstein, O., and Sand, A., Proc. Roy. Soc., B., 129, 256 (1940).

- Steinhausen, W., Pflïg. Arch. ge8. Physiol., 228, 323 (1931) ; 232,

500 (1933); Z̈. Laryngol. Rhinol., 26, 29 (1935).

${ }^{10}$ Lowenstein, O., Z. vergl. Physiol., 17, 806 (1932).

"Magnus, R., "Körperstellung", Berlin (1924).

${ }^{12}$ Adrian, E. D., J. Physiol., 101, 389 (1942).

\section{POWER AND PERSONAL LEADERSHIP}

$\mathrm{T}$ HE Thomas W. Salmon Memorial Lectures, given in previous years by psychiatrists, were delivered at the New York Academy of Medicine last November by Prof. H. D. Lasswell, a social scientist known mainly for his studies of propaganda and his applica. tion of psychoanalytic concepts to problems of political science. His topic was "The Dynamics of Power and Personality". "The long-run aim of societies aspiring towards human freedom," said Prof. Lasswell, "is to get rid of power and to bring into existence a free-man's commonwealth in which coercion is neither threatened, applied nor desired. This is the thread of anarchist idealism that appears in all uncompromising applications of the key conception of human dignity." But the more accessible goal, to which Prof. Lasswell gave his main attention, is to secure a democracy in which power is shared as widely as possible and is subordinated to respect for the dignity of the human personality. He therefore discussed the types of people who in our society seek for power and provide leadership. He saw them as drawn very largely from the middle class, as a result not of economic accident but of the psychological characteristics of the class, in particular its tradition of sacrificing immediate gratifications to the acquisition of skills which will ultimately bring a larger reward. "We know that middle-class homes are hothouses of ambition, holding their children to high standards of achievement, and providing the tension between indulgence and deprivation so congenial to the accentuation of power [as a goal]." Within the middle class, professional families contribute a disproportionately large number of leaders, partly because their tradition of public service deters them from seeking purely private advantage in business life. Prof. Lasswell seemed to imply that political leaders' ideals of public service are largely rationalizations of narrower personal needs for power.

It was the less admirable types of power-holder to whom Prof. Lasswell gave most attention. $\mathrm{He}$ distinguished the compulsive (or obsessional) type, often bureaucratic in inclination; the dramatizing type, highly concerned with the emotional response he can elicit from others, and characteristically producing the agitator; and the detached type, whose own emotional response is largely screened from his consciousness, and who may supply "useful judges, arbitrators, conciliators, diplomatic negotiators and scientists", but in whom "the absence of lively emotional states can lead to calm, pitiless, destructive conduct". Apropos the obsessional bureaucrat, Prof. Lasswell developed the interesting suggestion that he harbours strong unconscious hostility to the authority of the system he is serving, and by excessive scruples and doubts in interpreting detailed rules he forces his superiors to take responsibility which they had intended to delegate, and so undermines the authority that he means most scrupulously to obey.

Prof. Lasswell pointed out that to understand the destructive form of power seen in war we must attend not only to war itself but also to manifesta. tions of power found everywhere in our social struct. ure; and he suggested that "concentrations of destructive impulse" occur as a result of competitive practices that we take for granted in commerce, industry and public life. "It is impossible to abolish acute destructiveness without altering the equilibrium of the entire social process, since such acute disturb. ances mainly give vent to stress that has accumulated through the social system as a whole." Hence he advocated a "social psychiatry", one function of which would be to study the tensions created by "the struggle to express native impulses in ways forbidden by authority", the sexual impulse providing one example. For the rest, his prescription against war was "Physical Defence, Psychological Offence", and he urged the opponents of Marxism to emulate the Marxists' effectiveness in political education and propaganda, especially in giving the public as clear a conception as possible of the goal of national policies.

\section{THE FOURTH SOUTH AMERICAN CHEMICAL CONGRESS}

THE Fourth South American Chemical Congress was held in Santiago, Chile, during March 1-7, with more than four hundred delegates attending from all the South American republics. Invitations to attend were also extended to a number of countries outside South America: Great Britain was represented by Prof. J. W. Cook, Prof. E. C. Dodds and Dr. F. N. Woodward, the United States of America by Dr. Alfred Gauger, Sweden by Prof. The Svedberg and Republican Spain by Dr. Francisco Giral. 